DOI:10.17951/h.2016.50.3.49

\begin{tabular}{lcc}
\hline \multicolumn{2}{c}{ A N N A L E S } \\
UNIVERSITATIS & MARIAE CURIE-SKŁODOWSKA \\
LUBLIN - POLONIA & \\
VOL. L, 3 & SECTIOH H \\
\hline
\end{tabular}

Poznań University of Life Sciences. Faculty of Economics and Social Sciences

LIDIA ZOFIA JABEOŃSKA-PORZUCZEK

jplidka@up.poznan.pl

\title{
Threats to Retirement System Security
}

Zagrożenia bezpieczeństwa systemu emerytalnego

Keywords: social security; retirement system; economic and systemic risk

Słowa kluczowe: zabezpieczenie społeczne; system emerytalny; ryzyko gospodarcze i układowe

JEL Code: $\mathbf{H 5 5}$

\section{Introduction}

Safety and security are among the basic needs of individuals. Both notions have been subject to a dynamic evolution brought by socioeconomic changes. The present interpretation of security is not limited to the military sector. On the contrary, it has expanded to include the economic, social and ecological areas of human existence. The interest in safety and security is relevant to the role of the state, which should take proper care of its citizens, protecting their opportunities for development irrespective of their social or economic status. It should be the case especially in times of multiple threats affecting an individual's feelings of safety and security, including the inefficient system of social security, and therefore, ensure an improvement in the quality of their lives, not merely in material dimension, but also in the non-material one.

The paper aims to analyse retirement security with regard to the common social security system. The considerations involve reflections on various types of risk, among which the demographic, economic and systemic risk have been analysed in detail. The article also includes a review of basic issues connected with retirement security. 


\section{The notions of safety and security}

A number of definitions of safety and security can be found in relevant literature. According to Kukuła, security is the survival of the state which guarantees its territorial integrity and political independence [Kukuła, 1982, as quoted in: Księżopolski, 2004, p. 12]. Nowadays, security is not merely understood in a strictly military sense, since there are a number of threats other than military ones that can influence the feeling of security. Among these, the malfunctioning of the social or economic system of the state poses a serious threat. Their destabilisation leads to infringement of both social and economic security, which are mutually interconnected, and, apart from military security and political security, constitute the most important elements of state security. A high level of social security is ensured by a stable and economically sound state, which is able to meet its citizens' needs to a greater degree [Włoch, 2009, p. 96; Rosłon-Żmuda, 2013, pp. 176-177].

A proper standard of social security should be ensured by the social security scheme. One of its pillars is the old-age security, whose main aim is "to ensure a certain level of financial security in old age" [Szumlicz, 2006, p. 241]. However, apart from securing a certain level of material standard, it should also guarantee social security. For the proper functioning of the system, it is not merely the material aspect, but also the non-material one. It is the latter dimension in which the system can result in reducing the threats to an individual's development [Księżopolski, 2002, p. 20]. Such reasoning "originates from the legal system of a state that ensures social order, which is connected ensuring the right legal procedures that can be put in action whenever the difficult situation of individuals requires it (work guarantee or benefits in case of redundancy, feeling of future security)" [Kalinowski, 2014, pp. 390-391].

For the purposes of the present paper, what is of particular significance is the retirement system, which is connected with assuring a proper level of income for OAPs, i.e. an individual's prudence, but also ensuring the stability of the retirement system, i.e. the responsibility of the state. The state should ensure the security and stability of retirement systems through appropriate legal regulations. Retirement security is relevant to the aims of retirement systems, which include adequacy ${ }^{1}$ and resistance $^{2}$ [Holzman, Hinz, 2005; Barr, Diamond, 2008].

Retirement security is influenced by a number of complex external and internal factors. The most significant external factors include demographic determinants, as well as economic fluctuations affecting the labour market and the financial market. Internal factors include legal regulations which determine the subjective and objective scope of the retirement system, the amount of contributions and the level of benefits.

1 The system should guarantee proper benefits protecting from poverty and replacing incomes received in times of professional activity, the possibility of financing benefits and financial stability, i.e. the possibility of ensuring the promised benefits.

2 The retirement system should last in times of unpredicted economic or demographic conditions. 
These factors can be considered from the perspective of risks which pose threats to retirement security. The risks often arise due to inappropriate economic decisions resulting in various threats to the development of the state and the wealth of its citizens. Although retirement systems are prone to various types of risks, the major ones include demographic, economic and social risk [Chłon-Domińczak 2012, pp. 407-415].

\section{Demographic risk}

Demographic changes are an important factor that can influence the level of retirement security. Fluctuations in the population size as well as changes to its age structure can both influence the economic situation of the retirement system. The size of the working population affects a country's economic situation and the situation on its labour market, but from the perspective of retirement systems, it is also the size of the working-age subpopulation that matters. In the long run, what matters is also the size of the pre-working age population, since it affects the future numbers of both the insured and the beneficiaries.

Between 2000 and 2014, the number of Poland's population shrank from 38.64 million to 38.47 million, however, the decline mostly included the working-age population (63\% on average) (Table 1). It was also influenced by the drop in the share of pre-working-age subpopulation (from $24 \%$ to $18 \%$ ), the size of which decreased by $25 \%$. The share of post-working-age population was relatively lowest, but it showed an increasing trend (from 14\% to 19\%). A constant expansion of the population of elderly people is connected with their increasing lifespan. This, in turn, results from a number of factors, including improving living conditions and development of health care standards. The average lifetime expectancy of people born in 2000 amounts to 69.7 and 78 years for men and women respectively while the length of life of people born in 2014 will be even longer, amounting to 73.8 and 81.6 years for men and women respectively.

Table 1. Population across economic age groups (in millions)

\begin{tabular}{|l|r|r|r|r|r|r|r|r|r|r|r|r|r|r|r|}
\hline & 2000 & 2001 & 2002 & 2003 & 2004 & 2005 & 2006 & 2007 & 2008 & 2009 & 2010 & 2011 & 2012 & 2013 & 2014 \\
\hline $\begin{array}{l}\text { Pre-working- } \\
\text {-age }\end{array}$ & 9.30 & 8.97 & 8.66 & 8.35 & 8.09 & 7.86 & 7.66 & 7.49 & 7.34 & 7.23 & 7.14 & 7.14 & 7.07 & 6.99 & 6.94 \\
\hline Working-age & 23.66 & 23.92 & 23.79 & 24.04 & 24.24 & 24.4 & 24.48 & 24.54 & 24.59 & 24.62 & 24.62 & 24.74 & 24.6 & 24.42 & 24.23 \\
\hline $\begin{array}{l}\text { Post-work- } \\
\text { ing-age }\end{array}$ & 5.68 & 5.74 & 5.76 & 5.80 & 5.84 & 5.89 & 5.98 & 6.08 & 6.20 & 6.31 & 6.44 & 6.65 & 6.86 & 7.08 & 7.30 \\
\hline Total & 38.64 & 38.63 & 38.21 & 38.19 & 38.17 & 38.15 & 38.12 & 38.11 & 38.13 & 38.16 & 38.2 & 38.53 & 38.53 & 38.49 & 38.47 \\
\hline
\end{tabular}

Source: author's own study based on CSOP data.

The size of the population is affected by the evolution of the family. The number of marriages has been decreasing steadily (amounting to 211.000 in 2011 and 188.000 in 2014), and their durability seems to have weakened. The age of people 
getting married has been increasing ( 26 for men and 24 for women in 2000 vs. in $2014-29$ and 27 respectively) and so is the age of mothers giving birth to their first child (23.7 in 2000 vs. 29.2 in 2014).

The demographic transformation which is taking place in Poland also includes a rapid decrease in fertility rate, as well as the deterioration of women's fertility. In 2000 , for every 1000 women aged 15-49, the number of live births amounted to 438, and in 2014 the number amounted to 40, whereas it amounted to 76 in 1986 and 58 in 1990 respectively. The fertility rate declined from 1.35 in 2000 to 1.29 in 2014. The rate is primarily affected by the situation on the labour market, pro-family policy, as well as structural and cultural conflict. Bearing in mind the low values of the fertility rate, a system of such support should be introduced, which would guarantee a more efficient range of family benefits, paid parental leaves and flexible forms of employing mothers. It would also be recommended to increase the availability of day care centres and kindergartens, which could contribute to an increase in women's professional activity and diminishing the structural conflict connected with the opportunities and limitations of women's professional activity due to performing certain family roles. The cultural conflict concerns the views on the social roles of women and men in a given society, which also define the family model basing on the division of professional and family-related duties.

\section{Economic risk}

The decline in population size and the ageing of society both affect the socio-economic security of a state by diminishing labour supply, and consequently, the volume and the growth rate of GDP, destabilisation of public finance, revealed also in the crisis of the retirement system, and finally, retirement security.

The functioning of the retirement system is influenced by the level of employment, which, on the one hand, ensures high pensions, and on the other hand, guarantees the financial solvency of the system. Actions aimed at increasing employment and prolonging the period of professional activity have been taken in recent years. Withdrawal from the labour market always affects the level of retirement benefits. It mainly concerns retirement systems, in which the amount of pension depends on the length of paying contributions, i.e. the length of professional activity. The unemployed do not contribute to the national product and they increase budget expenses due to additional costs of paid benefits. Leaving the labour force also results in increased labour costs which limit labour demand and lead to a growth in budget deficit. Maintaining an expensive retirement system also requires increased contributions, which, in turn, amplify non-wage costs of employment. This discourages employers from taking on more staff and in the end leads to a decline in income in retirement systems. If the whole retirement system is financed from the state budget, a decline in employment also results in a decline in budgetary income since tax income declines as well. 
Between 2000 and 2014, basic labour market indices were subject to considerable fluctuations. The average value of professional activity ratio ranged from $55 \%$ to $48 \%$, but these figures were relatively low in comparison to other EU countries (a corresponding value for EU28 amounted to 60-70\%) (Table 2). The increase of the employment ratio is encouraged by the increasing popularity of fixed-term employment, part-time employment, self-employment, work under contracts and seasonal work. The transformation of the labour market has become a challenge for retirement systems. On the one hand, these non-standard forms of employment may result in shifts between insurance entitlements which can negatively influence the volume of benefits granted in future periods, as well as limit incomes from paid contributions. On the other hand, it can result in an overall increase in the number of insured citizens. The transformation of the labour market is a consequence of Poland's accession to the EU since it is the European employment policy that strives for an equilibrium between labour market flexibility and job security [Council of the European Union, 2006].

Table 2. Professional activity ratio, employment ratio (in \%)

\begin{tabular}{|l|r|r|r|r|r|r|r|r|r|r|r|r|r|r|r|}
\hline & 2000 & 2001 & 2002 & 2003 & 2004 & 2005 & 2006 & 2007 & 2008 & 2009 & 2010 & 2011 & 2012 & 2013 & 2014 \\
\hline $\begin{array}{l}\text { Professional } \\
\text { activity ratio }\end{array}$ & 56.4 & 55.8 & 55.0 & 54.8 & 54.9 & 55.2 & 54.1 & 54.1 & 54.7 & 55.1 & 55.8 & 53.3 & 55.9 & 56.1 & 56.3 \\
\hline $\begin{array}{l}\text { Employment } \\
\text { ratio }\end{array}$ & 47.4 & 45.5 & 44.1 & 44.2 & 45.1 & 45.9 & 47.5 & 49.5 & 51 & 50.4 & 50.6 & 46.4 & 50.2 & 50.6 & 51.7 \\
\hline
\end{tabular}

Source: author's own study based on CSOP.

According to M. Góra's [2003] definition, the retirement system is a method of dividing the current GDP between the working population and the pensioners. Hence, the retirement system is directly connected with the volume of GDP. Financing the retirement system, and thus the standard of pensioners' living situation, depends on the rate of growth [Żukowski, 2009, pp. 404-406]. Between 2000 and 2014, GDP in constant prices fluctuated between 101.2 and 107.2 (Table 3).

Table 3. Dynamics of GDP growth (constant prices)

\begin{tabular}{|l|l|l|l|l|l|l|l|l|l|l|l|l|l|l|}
\hline 2000 & 2001 & 2002 & 2003 & 2004 & 2005 & 2006 & 2007 & 2008 & 2009 & 2010 & 2011 & 2012 & 2013 & 2014 \\
\hline 104.6 & 101.2 & 102.0 & 103.6 & 105.1 & 103.5 & 106.2 & 107.2 & 103.9 & 102.6 & 103.7 & 104.8 & 101.8 & 101.7 & 103.5 \\
\hline
\end{tabular}

Source: CSOP data.

It needs to be emphasised that there are mutual dependencies between gross national product and the retirement system ${ }^{3}$, i.e. it is not sufficient to claim that the level of benefits depends on the level of GNP. The functioning of an economy

\footnotetext{
3 More information in [Żukowski, 2009, pp. 401-411].
} 
depends on the retirement system as well. By certain legal regulations, it influences professional activity as well as diminishes and compensates for the consequences of social risks, i.e. ensures incomes in old age.

\section{Systemic risk}

Retirement security is determined by legal regulations which describe the subjective and objective scope of the system. The retirement system has been subject to major transformation since the very beginning of its reform, including changes to the subjective scope, an increase in the retirement age and a modification of the second pillar of the system. The main aim of the introduced regulations was to alleviate the consequences of population ageing, to limit its influence on economic growth and also to improve the financial condition of the retirement system. However, it should be emphasised that legal changes may result from the need of systemic or political changes (especially in the pre-election period) or court sentences (mainly those issued by the Constitutional Tribunal of Poland) [Chłon-Domińczak 2012, p. 415]. The introduced amendments influence the retirement/pension security of both an individual and the system. What matters for an individual belonging to the system is the range of protection, while for the system it is the level of incomes and expenditures.

Between 2000 and 2014, both incomes and expenditures of the Social Insurance Fund increased but incomes grew slightly more than expenditures (130\% and $117 \%$ respectively) (Figure 1). The increase in incomes was connected with the increase in the number of insured citizens (from 13.0 to $14.5 \mathrm{~m}$ ) resulting from, among others, increased retirement age but also the introduced regulations concerning the second pillar ${ }^{4}$. These regulations contributed to an increase in the incomes from contributions but at the same they meant a decrease in contribution reimbursement to OPF. Contributions accounted for the highest share in total incomes, amounting to $70 \%$. Subsidies from the state budget also constituted an important share $(22 \%)$ of incomes. They increased continually for 13 years reaching a peak of 40 billion in

4 In 2011, the interest rate of the contribution paid to Open Pension Funds (OPF) changed. It was set at $2.3 \%$ of the assessment basis between 01.05 .2011 and 31.12 .2012 , reaching $2.8 \%$ for the period between 01.01 .2013 and $31.12 .2013,3.1 \%$ for the period between 01.01 .2014 and $31.12 .2014,3.3 \%$ for the period between 01.01 .2015 and 31.12.2016, and 3.5\% for the period starting on 01.01.2017 (Act of amendment to certain acts connected with the functioning of the social insurance system). The process of gradual working age prolongation started in 2013. Women aged 67 will retire in 2040, while men aged 67 will retire in 2020 . At the same time, membership in OPF has been voluntary for all insured citizens since 2014, which consists in their choice whether to allocate a part of their contribution funds to OPF or to register all their funds with the Polish Social Security Institution (Zakład Ubezpieczeń Społecznych ZUS) (Act of amendment to certain acts connected with defining the rules of pension payments from open pension funds). An additional mechanism of the so-called "security zip" was introduced. The mechanism assumes that 10 years before retirement, the funds gathered by the insured person with OPF will be transferred to the Social Insurance Fund and recorded on an individual subaccount. 
2012 but afterwards they started to fall as a result of the increase in contributions. In the analysed period of time, subsidies amounted to $2.5 \%$ of GDP in current prices. Their level has a direct effect on public finance, since it amounts to a substantial proportion of all expenditure (10\% on average). The level of subsidising depends on total income from contributions which, apart from internal factors, are also influenced by external factors, such as the situation on the labour market, the level of employment and the level of remunerations. The level of subsidising also influences the security of the retirement system, as it needs to cover the deficit of the Social Insurance Fund resulting from an increase in the expenses which are in a way guaranteed by the state. It is a worrying fact that the coverage ratio of income from contributions to expenses declined from $79.6 \%$ in 2000 to $68.5 \%$ in 2014 . Between 2000 and 2014, financial means transferred to individuals constituted the largest

\section{Income}

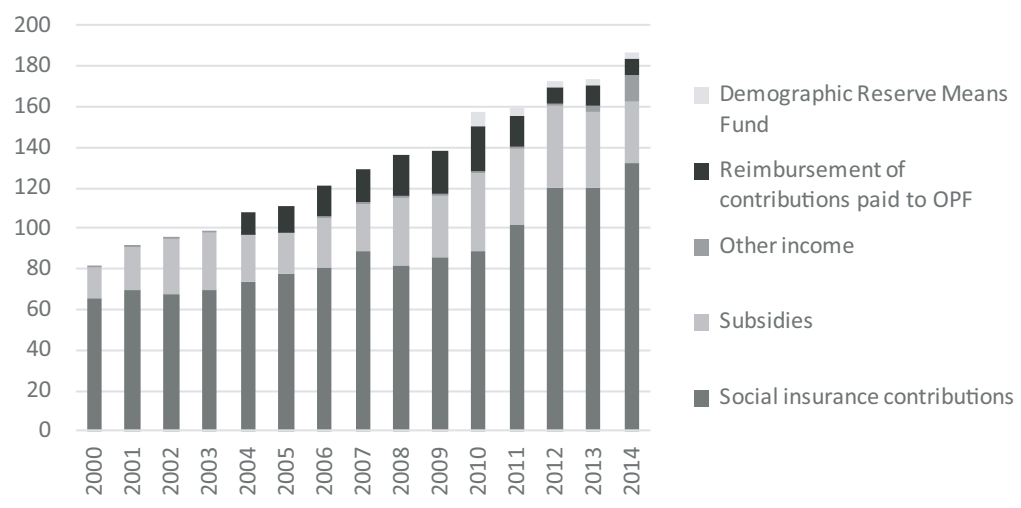

\section{Expenditure}

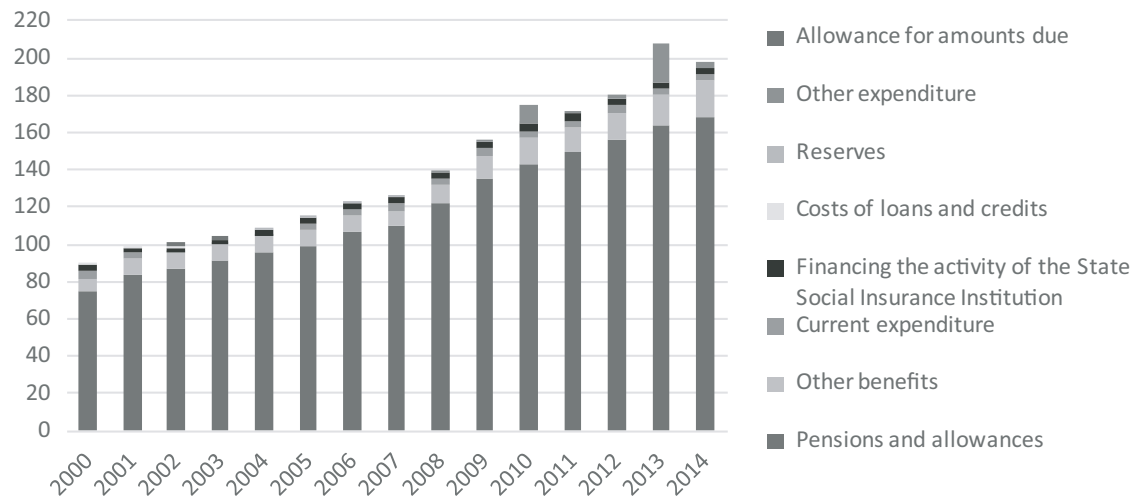

Figure 1. Income and expenditure of the State Social Insurance Fund 2000-2014 (billions of PLN) Source: author's own study based on state budget execution report. 
proportion of all expenditures, with pensions and medical allowances amounting to $87 \%$. Most benefits were paid from the pension fund (approximately $60 \%$ ) and they contributed to between $5.9 \%$ to $7 \%$ of GDP (2000 and 2014 respectively). Pension expenses depend mainly on the number of beneficiaries and the level of pensions paid. In the analysed 15-year period of time, the number of pensioners obtaining benefits from the Social Insurance Fund increased by 49\% (from 3.3 million to 4.9 million). The increase in the number of beneficiaries results mainly from systemic reasons, e.g. making earlier retirement possible until 2009. It needs to be emphasised that the current retirement system exerts an influence on future pensioners' decisions concerning their retirement, which was confirmed in survey research conducted on 350 pensioners obtaining pensions from the Polish Social Security Institution in 2009 and 2010. Respondents were mainly determined to retire because of fulfilling all conditions to obtain the benefit, but also as a result of becoming entitled to retire after a long period of paying contributions (nearly $60 \%$ of the surveyed). Fulfilling the condition of being entitled to retire is, in a way, a determining factor making people retire since they fear changes in legal regulations in this respect.

In the analysed period, an average pension increased by $113 \%$ (from PLN 957.67 to $2,043.08$ ) but pensions granted according to new regulations were on average 1,000 lower than the benefits granted according to old regulations (Table 4).

Table 4. Average pension level

\begin{tabular}{|l|c|c|c|c|c|}
\hline & 2010 & 2011 & 2012 & 2013 & 2014 \\
\hline Pension grantem according to new rules & $1,711.69$ & $1,694.84$ & $1,728.50$ & $1,856.50$ & $1,975.53$ \\
\hline Pension grantem according to old rules & $2,493.14$ & $2,660.55$ & $2,759.89$ & $3,036.82$ & $3,182.24$ \\
\hline
\end{tabular}

Source: author's own study based on Polish State Insurance Institution data.

It needs to be remembered that the level of benefits depends on a number of factors including the length of professional activity, the level of remunerations and the indexation of benefits. In order to prolong the period of individuals' professional activity and to increase their responsibility for the amount of pension granted, retirement age was increased. In the analysed period of time, the average age of a pensioner rose by 3 years. The value of minimum wage increased, too (from 700.00 to 1,680.00) and so did the value of average wage in Poland (from PLN 1,923.81 to 3,783.46). The current rules assume an almost automatic indexation of pensions and annuities. In the analysed period of time, these benefits were indexed nearly every year, except for 2005 . The average index value amounted to $104 \%$.

The main source of income for the elderly are social insurance benefits. For pensioners, it is the pension which amounts to $80 \%$ of their total incomes. The meaning of social benefits is thus huge but beneficiaries who are willing to ensure a proper level of incomes also try to obtain earnings from other sources, i.e. remunerated work, self-employment or lease of real estates. It needs to be emphasised that the incomes of the elderly are relatively high in comparison to the incomes 
of young people and their level is relatively high both in Poland and in the EU. In 2011 , the median of disposable incomes of people over 65 amounted to $94 \%$ of the median of disposable incomes of people aged below 65 . The average ratio for the EU amounted to $89 \%$, the highest benefits were obtained in Luxembourg (105\%) and France (101\%), whereas lowest benefits were granted in Cyprus (65\%), Bulgaria and Denmark (72\%) [Eurostat, 2013, p. 185].

\section{Conclusions}

Based on the insurance method, the retirement system has fulfilled its major function, i.e. protected citizens from poverty. Nowadays, the system fails to meet its basic protective function. The socio-economic transformation results in an increase in systemic inefficiency in this respect. The progress of technology and civilisation and the improvement in living standards resulted in changes in the labour market and arousal of new forms of employment. Starting a professional activity does not only depend on an individual's level of education or its quality, their qualifications or skills, but also their flexibility and mobility. The existence of business entities depends on overall business outlook, tax burden and parafiscal labour costs. Attempting to minimise labour costs, employers prefer flexible forms of employment which typically decrease the level of retirement security. It needs to be remembered that some employment forms exert a negative influence on the functioning of the social insurance system decreasing contributions and increasing the level of subsidising from state budget and consequently, decreasing the competitiveness of the economy and its capability to create new places of work. Such situation also influences the amount of pensions. Unemployment, low remuneration and irregularity of paid contributions all result in a situation where future pensions do not meet pensioners' needs and frequently fail to protect them against poverty.

It can be concluded that the level of retirement security has declined in recent years. The state budget finances the developing systemic deficit. It needs to be emphasised that the level of subsidising was much lower before the introduction of the reform. It amounted to PLN 881 million in 1990 and later increased to PLN 8 billion in 1998 and PLN 40 billion in 2012. In order to decrease the share of financing the deficit from state budget, changes are frequently introduced to legal regulations. They result in disinformation and growing insecurity among the members of the system. The willingness to retire immediately after obtaining the entitlement to do so also increases the general dissatisfaction with the retirement system. In general, the amount of pension paid does not ensure social security. Benefits granted according to new rules are much lower than those granted according to old rules. The reformed retirement system is also prone to risk which has to be faced by future beneficiaries. The new system may be perceived as a threat to ensuring a certain income in old age. It is even more probable given the predicted low rates of replacement and the 
low popularity of voluntary saving for future pensions. The present retirement system also faces a number of threats, also due to the fact that it requires participants to constantly adjust to the changing demographic and socio-economic conditions.

\section{Bibliography}

Barr N., Diamond P., Reforming Pensions: Principles, Analytical Errors and Policy Directions, "International Social Security Review” 2008, November, http://econ.lse.ac.uk/staff/nb/Barr Diamond_crr.pdf [access: 27.01.2012], DOI: http://dx.doi.org/10.2139/ssrn.1315444.

Chłoń-Domińczak A., Ubezpieczenia społeczne jako podstawowy instrument bezpieczeństwa socjalnego obywateli, [w:] K. Raczkowski (red.), Bezpieczeństwo ekonomiczne. Wyzwania dla zarządzania państwem, Oficyna Ekonomiczna Grupa Wolters Kluwer Polska, Warszawa 2012.

Council of the European Union, Press Release $2733^{\text {rd }}$ Council Meeting Employment, Social Policy, Health and Consumer Affairs Luxembourg, 1-2 June 2006.

Eurostat, European Social Statistic, Luxemburg 2013.

Góra M., System emerytalny, PWE, Warszawa 2003.

GUS, Mały Rocznik Statystyczny Polski 2015, Warszawa 2015.

GUS, Rocznik Statystyczny Rzeczypospolitej Polskiej (za lata 2000-2014), Warszawa 2000-2014.

Holzman R., Hinz R., Old-Age Income Support in the 21 $1^{\text {st }}$ Century: An International Perspective on Pension Systems and Reform, The World Bank, Washington 2005, www.apapr.ro/images/BIBLIOTECA/ reformageneralitati/bm\%20income\%20support\%202005.pdf [access: 27.01.2012],

DOI: http://dx.doi.org/10.1596/0-8213-6040-x.

Kalinowski S., Pewni niepewności, [w:] Z. Galor, B. Goryńska-Bittner, S. Kalinowski (red.), Życie na skraju - marginesy społeczne wielkiego miasta, Societas Pars Mundi Publishing, Bielefeld 2014.

Księżopolski K.M., Ekonomiczne zagrożenia bezpieczeństwa państw. Metody i środki przeciwdziałania, Dom Wydawniczy Elipsa, Warszawa 2004.

Księżopolski M., Bezpieczeństwo socjalne, [w:] B. Rysz-Kowalczyk (red.), Leksykon polityki społecznej, Instytut Polityki Społecznej Uniwersytetu Warszawskiego, Oficyna Wydawnicza ASPRA-JR, Warszawa 2002.

Kukuła J., Bezpieczeństwo a wspótpraca europejska: współzależności i sprzeczności interesów, „Sprawy Międzynarodowe" 1982, nr 7.

Rada Ministrów, Sprawozdanie z wykonania budzetu państwa za okres od 1 stycznia do 31 grudnia (za lata 2000-2014), Warszawa 2001-2015.

Rosłon-Żmuda J., Bezpieczeństwo społeczno-ekonomiczne Polski z perspektywy czynnika demograficznego, „Przegląd Strategiczny” 2013, nr 1.

Szumlicz T., Ubezpieczenie społeczne - teoria dla praktyki, Oficyna Wydawnicza Branta, BydgoszczWarszawa 2006.

Ustawa z dnia 17 grudnia 1998 r. o emeryturach i rentach z FUS (Dz.U. z 1998 r., nr 162, poz. 1118).

Ustawa z dnia 25 marca 2011 r. o zmianie niektórych ustaw związanych z funkcjonowaniem systemu ubezpieczeń społecznych (Dz.U. z 2011 r., nr 75, poz. 398).

Ustawa z dnia 6 grudnia 2013 r. o zmianie niektórych ustaw w związku z określeniem zasad wypłaty emerytur ze środków zgromadzonych w otwartych funduszach emerytalnych (Dz.U. z 2013 r., poz. 1717).

Włoch R., Bezpieczeństwo ekonomiczne państwa, [w:] K.A. Wojtaszczyk, A. Materska-Sosnowska (red.), Bezpieczeństwo państwa, Oficyna Wydawnicza Aspra, Warszawa 2009.

ZUS, Rocznik statystyczny ubezpieczeń społecznych system pozarolniczy 1999-2002, Warszawa 2004.

ZUS, Rocznik statystyczny ubezpieczeń społecznych 2006-2008, Warszawa 2009.

ZUS, Rocznik statystyczny ubezpieczeń społecznych 2009-2011, Warszawa 2012.

ZUS, Ważniejsze informacje z zakresu ubezpieczeń społecznych 2005 r., Warszawa 2006. 
ZUS, Ważniejsze informacje z zakresu ubezpieczeń społecznych 2014 r., Warszawa 2015.

Żukowski M., Zwiąki ubezpieczenia emerytalnego z gospodarka, [w:] A. Patulski, K. Walczak (red.), Jedność w różnorodności. Studia z zakresu prawa pracy, zabezpieczenia społecznego i polityki społecznej. Księga pamiątkowa dedykowana Profesorowi Wojciechowi Muszalskiemu, C.H. Beck, Warszawa 2009.

\section{Zagrożenia bezpieczeństwa systemu emerytalnego}

Celem publikacji jest analiza bezpieczeństwa emerytalnego w odniesieniu do powszechnego systemu zabezpieczenia społecznego. Podjęto także rozważania dotyczące ryzyk, które zagrażają bezpieczeństwu emerytalnemu. Szczególną uwagę zwrócono na ryzyko demograficzne, gospodarcze i systemowe. W pracy dokonano przeglądu podstawowych zagadnień związanych z bezpieczeństwem emerytalnym i wykorzystano elementy statystyki opisowej. Źródłem danych są statystyki Zakładu Ubezpieczeń Społecznych, Głównego Urzędu Statystycznego i Eurostatu. Z analizy danych wynika, że w ostatnich latach zmniejszyło się bezpieczeństwo emerytalne. Budżet państwa przez dotacje w znacznym stopniu finansuje powstający deficyt systemu. Aby zmniejszać udział państwa w dotowaniu systemu, wprowadzane są częste zmiany regulacji prawnych. Przyczyniają się one do powstania dezinformacji i wzrostu niepewności wśród uczestników systemu.

\section{Threats to Retirement System Security}

The aim of the paper is to analyse the retirement safety with reference to the common social security system. It also includes consideration of risks which threaten retirement security. Particular attention is paid to demographic, economic, and systemic risk. The paper includes a review of basic notions connected with retirement security. Elements of descriptive statistics have also been used. Data was obtained from the Polish Social Security Institution (ZUS), Central Statistical Office of Poland (GUS) and Eurostat. Analysis shows that retirement security has decreased in recent years. The state budget has been financing a substantial part of a systemic deficit. In order to decrease the share of state subsidies, frequent amendments to legal regulations are introduced. These, nevertheless, increase disinformation and increase uncertainty among the member of the retirement system. 